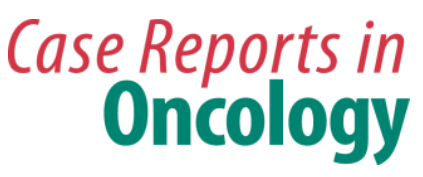

Case Rep Oncol 2017;10:447-451

DOI: $10.1159 / 000475755$

Published onlıne: IVlay 16, 2017
(C) 2017 The Author(s)

Published by S. Karger AG, Basel

www.karger.com/cro

This article is licensed under the Creative Commons Attribution-NonCommercial 4.0 International License (CC BY-NC) (http://www.karger.com/Services/OpenAccessLicense). Usage and distribution for commercial purposes requires written permission.

\title{
Good Tolerance to Full-Dose Crizotinib in a Patient with Anaplastic Lymphoma Receptor Tyrosine Kinase-Rearranged Lung Adenocarcinoma and Preexisting Renal Impairment
}

\author{
Adeline Rosoux Fabrice Duplaquet Sebahat Ocak \\ Division of Pulmonology, CHU UCL Namur, Université catholique de Louvain (UCL), \\ Yvoir, Belgium
}

\section{Keywords}

Crizotinib $\cdot$ Full-dose $\cdot$ Lung adenocarcinoma $\cdot$ Renal dysfunction

\begin{abstract}
Background: Crizotinib is an approved tyrosine kinase inhibitor in the treatment of advanced-stage non-small-cell lung cancer patients with anaplastic lymphoma receptor tyrosine kinase (ALK) rearrangement. Renal dysfunction after crizotinib administration was recently reported, but the physiopathological explanation and the safety in patients with preexisting renal dysfunction are still not clear. Case Presentation: A 44-year-old female and current smoker was diagnosed with a stage IV lung adenocarcinoma and treated with five lines of chemotherapy during a 4-year period of time. While she developed symptomatic tumor progression with deterioration of her performance status and renal dysfunction after these five lines of treatment, we discovered that her lung cancer was ALK-rearranged. We therefore proposed a treatment with full-dose crizotinib despite the renal impairment (creatinine clearance: $33 \mathrm{~mL} / \mathrm{min} / 1.73 \mathrm{~m}^{2}$ ) of unknown origin. A renal function worsening occurred after the initiation of crizotinib but we did not reduce the dose as recommended and this did not induce further deterioration. During the 15 months under crizotinib, the patient had a good
\end{abstract}




\section{Case Reports in Oncology}

general status, no clinically noticeable side effect, and a stable renal dysfunction, which even improved after the initial worsening and almost returned to the baseline (pre-crizotinib) status. Conclusion: This case report suggests that full-dose crizotinib may be continued even in patients with severe renal dysfunction and deterioration at treatment initiation, in parallel to careful follow-up of renal function and particular attention to avoid the use of concomitant nephrotoxic drugs.

\section{Background}

Crizotinib is an approved tyrosine kinase inhibitor in the treatment of advanced-stage non-small-cell lung cancer (NSCLC) patients with anaplastic lymphoma receptor tyrosine kinase (ALK) rearrangement [1-4]. Common side effects of crizotinib include digestive toxicity, visual disturbances, and fatigue. Renal dysfunction after crizotinib administration was recently reported, but the physiopathological explanation and the safety in patients with preexisting renal dysfunction are still not clear.

While it is recommended to decrease the dose of crizotinib in presence of renal insufficiency, we report in this article a case of good tolerance to full-dose crizotinib in a heavily pretreated patient with preexisting renal impairment.

\section{Case Presentation}

A 44-year-old female and current smoker was diagnosed with a stage IV lung adenocarcinoma and treated with five lines of chemotherapy, including a platinum-based doublet, during a 4-year period of time. While she developed symptomatic tumor progression with deterioration of her performance status (ECOG 2), and renal dysfunction after these five lines of treatment, we discovered that her lung cancer was ALK-rearranged. We therefore proposed a treatment with full-dose crizotinib $(250 \mathrm{mg}$ twice a day) despite the renal impairment (creatinine: $2.22 \mathrm{mg} / \mathrm{dL}$; creatinine clearance: $33 \mathrm{~mL} / \mathrm{min} / 1.73 \mathrm{~m}^{2}$ according to the Cockcroft-Gault equation) of unknown origin. Renal biopsy was estimated unsafe and was not performed because the patient had a solitary kidney (a nephrectomy had been performed when she was 18 years old for an unclear reason). In the absence of explanation provided by 24-hour urine analysis, blood tests, and urinary tract imaging, we hypothesized that the renal dysfunction was secondary to anti-inflammatory drugs used for headaches and/or to the nephrotoxicity of anterior chemotherapy agents. Few weeks after the initiation of full-dose crizotinib, she recovered a good general status (ECOG 0) and thoracoabdominal computed tomography confirmed a partial tumor response. We therefore pursued crizotinib at the same dose despite a worsening of the renal function (creatinine: $3.36 \mathrm{mg} / \mathrm{dL}$; creatinine clearance: $22 \mathrm{~mL} / \mathrm{min} / 1.73 \mathrm{~m}^{2}$ ), for which there was no other explanatory condition. During the 15 months under crizotinib, the patient had a good general status, no clinically noticeable side effect, and a stable renal dysfunction, which even improved after the initial worsening and almost returned to the baseline (pre-crizotinib) status (Fig. 1, Fig. 2). After 15 months, she experienced tumor progression and her general status quickly declined, leading to death 3 months later. 


\section{Case Reports in Oncology}

\section{Discussion}

This case shows acceptable renal tolerance to full-dose crizotinib in a patient with a preexisting renal dysfunction of unknown origin. Despite a worsening of the renal function at the beginning of the treatment, we decided to pursue crizotinib without reducing its dose and this did not induce further deterioration.

Recently, few articles reported the renal toxicity of crizotinib [5-7]. A case of acute renal dysfunction following crizotinib administration was first reported in a patient with stage IV NSCLC and no preexisting renal condition, with improvement after treatment discontinuation and worsening again after treatment rechallenge [6]. Then, a retrospective study evaluated renal function in 38 patients with stage IV NSCLC treated with crizotinib, including four cases with preexisting severe or moderate renal insufficiency (estimated glomerular filtration rate [eGFR] $\leq 60 \mathrm{~mL} / \mathrm{min} / 1.73 \mathrm{~m}^{2}$ ] [5]. They observed a mean $23.9 \%$ decrease in eGFR $(p<0.0001)$, with most of the decrease occurring within the first 2 weeks of treatment. The relation of crizotinib to renal dysfunction remained significant after adjustment for coexisting conditions such as dehydration, concomitant nephrotoxic drugs, or tumor lysis. After stopping crizotinib, recovery in eGFR occurred within the first weeks and was complete in $56.3 \%$, while partial ( $84-97 \%$ of baseline) in $43.8 \%$ of patients. Based on the early onset, minimal cumulative effect, and rapid reversibility of the renal dysfunction, the authors hypothesized that this may be a pharmacological effect and/or an interference with glomerular creatinine secretion rather than a direct nephrotoxic effect. Another case report described the worsening of a chronic kidney disease under crizotinib, once again with very clear correlation with crizotinib withdrawal and rechallenge [7]. Finally, a recent report on two patients treated with crizotinib (one with preexisting renal impairment) showed that crizotinib was associated with both acute and chronic effects on kidney function [8]. Acute effects reflect the decrease in creatinine-based measures of GFR, with non-creatinine-based measures remaining unchanged, while chronic changes reflect a reduction in true GFR. Mechanisms of renal deterioration following crizotinib administration are still not fully understood. In addition to the possible inhibition of the creatinine transporter in the proximal tubule, it has been postulated that the inhibition of MET, which is expressed in normal adult nephron and another target of crizotinib, may contribute to the renal toxicity $[5,7]$.

As described in the four articles described above [5-8], our patient experienced renal function deterioration soon after crizotinib initiation. However, as opposed to their cases with renal dysfunction, we did not reduce the dose of crizotinib or transiently discontinued it in our patient. Despite this, we did not observe further worsening of the renal impairment.

\section{Conclusion}

This case report suggests that full-dose crizotinib may be continued even in patients with severe renal dysfunction and deterioration at treatment initiation, in parallel to careful follow-up of renal function and particular attention to avoid the use of concomitant nephrotoxic drugs.

\section{Statement of Ethics}

The authors have no ethical conflicts to disclose. 
Rosoux et al: Good Tolerance to Full-Dose Crizotinib in a Patient with Anaplastic Lymphoma Receptor Tyrosine Kinase-Rearranged Lung Adenocarcinoma and Preexisting Renal Impairment

\section{Disclosure Statement}

This research did not receive any specific grant from funding agencies in the public, commercial, or not-for-profit sectors.

\section{References}

1 Camidge DR, Bang YJ, Kwak EL, Iafrate AJ, Varella-Garcia M, Fox SB, Riely GJ, Solomon B, Ou SH, Kim DW, et al: Activity and safety of crizotinib in patients with ALK-positive non-small-cell lung cancer: updated results from a phase 1 study. Lancet Oncol 2012;13:1011-1019.

-2 Kwak EL, Bang YJ, Camidge DR, Shaw AT, Solomon B, Maki RG, Ou SH, Dezube BJ, Janne PA, Costa DB, et al: Anaplastic lymphoma kinase inhibition in non-small-cell lung cancer. N Engl J Med 2010;363:16931703.

-3 Shaw AT, Kim DW, Nakagawa K, Seto T, Crino L, Ahn MJ, De Pas T, Besse B, Solomon BJ, Blackhall F, et al: Crizotinib versus chemotherapy in advanced ALK-positive lung cancer. N Engl J Med 2013;368:2385-2394.

4 Solomon BJ, Mok T, Kim DW, Wu YL, Nakagawa K, Mekhail T, Felip E, Cappuzzo F, Paolini J, Usari T, et al: First-line crizotinib versus chemotherapy in ALK-positive lung cancer. N Engl J Med 2014;371:21672177.

5 Brosnan EM, Weickhardt AJ, Lu X, Maxon DA, Baron AE, Chonchol M, Camidge DR: Drug-induced reduction in estimated glomerular filtration rate in patients with ALK-positive non-small cell lung cancer treated with the ALK inhibitor crizotinib. Cancer 2014;120:664-674.

-6 Gastaud L, Ambrosetti D, Otto J, Marquette CH, Coutts M, Hofman P, Esnault V, Favre G: Acute kidney injury following crizotinib administration for non-small-cell lung carcinoma. Lung Cancer 2013;82:362-364.

7 Martin Martorell P, Huerta Alvaro M, Solis Salguero MA, Insa Molla A: Crizotinib and renal insufficiency: a case report and review of the literature. Lung Cancer 2014;84:310-313.

8 Camidge DR, Brosnan EM, DeSilva C, Koo PJ, Chonchol M: Crizotinib effects on creatinine and noncreatinine-based measures of glomerular filtration rate. J Thorac Oncol 2014;9:1634-1637.

\section{Creatinine $(\mathrm{mg} / \mathrm{dL})$}

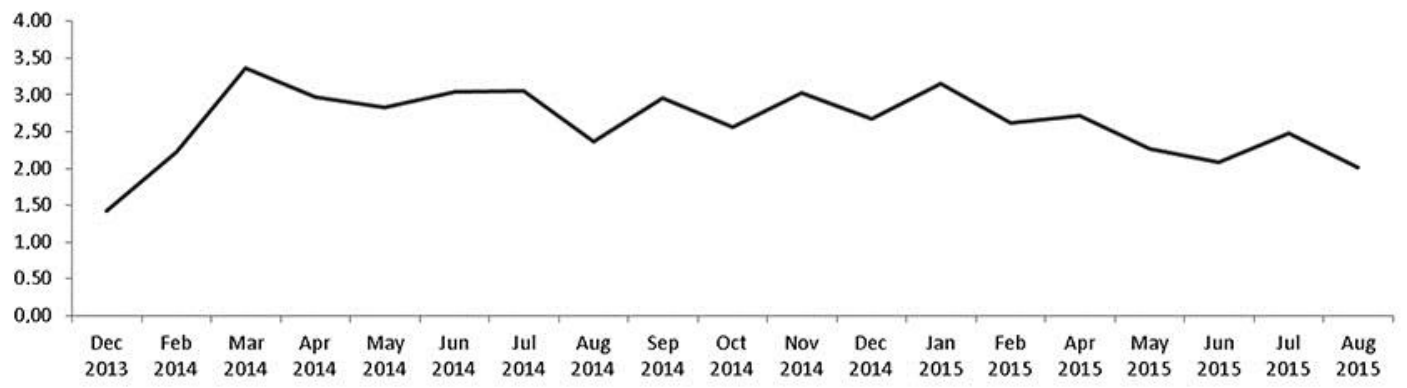

Fig. 1. Serum creatinine levels $(\mathrm{mg} / \mathrm{dL})$ during crizotinib treatment. 
Rosoux et al.: Good Tolerance to Full-Dose Crizotinib in a Patient with Anaplastic Lymphoma Receptor Tyrosine Kinase-Rearranged Lung Adenocarcinoma and Preexisting Renal Impairment

\section{Creatinine clearance $\left(\mathrm{mL} / \mathrm{min} / 1.73 \mathrm{~m}^{2}\right)$}

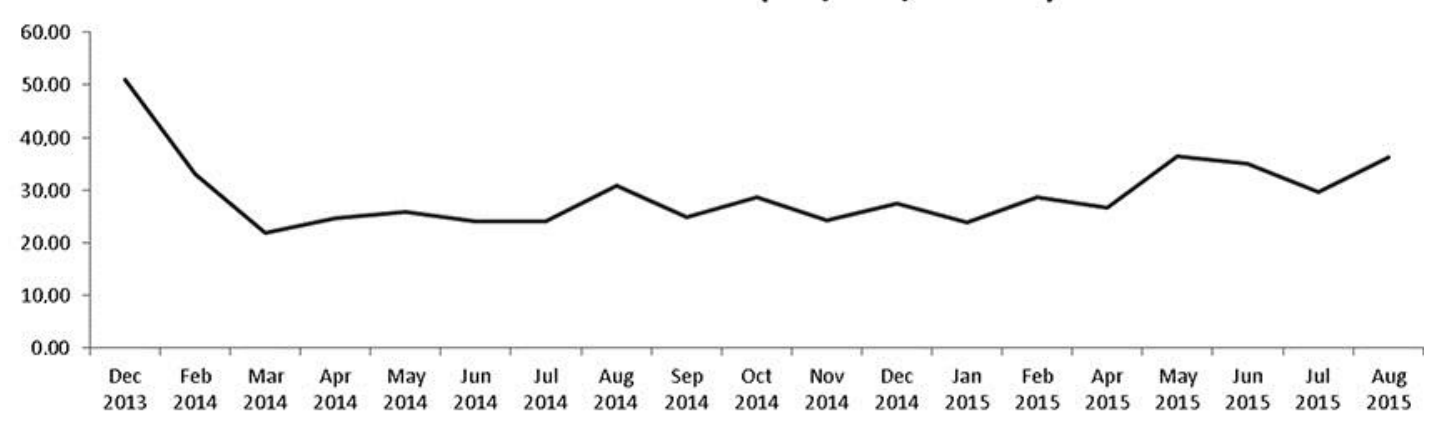

Fig. 2. Creatinine clearance levels $\left(\mathrm{mL} / \mathrm{min} / 1.73 \mathrm{~m}^{2}\right)$ during crizotinib treatment. Creatinine clearance was calculated according to the Cockcroft-Gault equation: creatinine clearance $=\operatorname{sex} \times[(140-$ age $) /($ serum creatinine) $] \times$ [weight/72]. Male: 1 ; female: 0.85 . 